\title{
The Holocaust Journal of Miksa Fenyö
}

\author{
Maya J. Lo Bello
}

\begin{abstract}
For readers today, first-person accounts provide one of the most effective means of gaining an intimate glimpse into the everyday lives of those experiencing historical events. Diary entries recorded during the Holocaust not only individualize the process of mass extermination, they also preserve the words of those bearing witness to horrendous crimes. Yet should these written records only be interpreted as works of non-fiction? What literary techniques might have been employed in creating these depictions? Other than the period in which they were written, what characteristics may diaries written during the Holocaust share? In an attempt to address a few issues posed by Holocaust journals and diaries, this paper examines Miksa Fenyő's Holocaust journal, Az elsodort ország ['A Country Adrift'] (1946), written while the author was in hiding from June 22, 1944 to January 19, 1945 in Budapest, Hungary.
\end{abstract}

Keywords: Holocaust in Hungary, diaries, historical narration, life-writing, Nyugat

Biography: Maya J. Lo Bello is currently a Ph.D. student at Eötvös Loránd University’s Department of Modern Hungarian Literature and Language. Her research focuses on Miksa Fenyö's role in establishing the journal, Nyugat ['West'], as well as his contributions to literary criticism. Other than editing a collected volume of Miksa Fenyö's writings, Maya J. Lo Bello also translates Hungarian literature into English.

As a teenager growing up in the United States, The Diary of Anne Frank was my first encounter with Holocaust literature. For me, her journal entries turned the vast numbers spoken of on TV and in history books into one heartbreakingly young face, a face not much older than mine at the time. I did not question the authenticity of Anne Frank's representation of events. Her words were so personal, her story so tragic, I had no choice but to believe in their veracity. Years passed before I noticed that the edition I read had been abridged, a realization that led to the discovery of the role played by her father, Otto Frank, in editing the diary. Otto Frank's decisions not only reflect the complex circumstances influencing how works of life-writing are published, they also serve to question Anne's status as author of her own diary: indeed, in the current legal battle surrounding The Diary's induction into the public domain, the Anne Frank 
Foundation argues that Otto Frank earned the book's copyright, not Anne. ${ }^{1}$ While these circumstances do not alter the impact Anne Frank's diary had on me, they do reveal a number of questions relevant to the nature of diaries and their role in bearing witness to historical events. Do readers place too much of a burden on individualized accounts when using them to confirm the daily events of mass extermination? As Francine Prose argues in her book, Anne Frank: The Book, the Life, the Afterlife (2011) should a text written with the purpose of bearing witness also be viewed as a work possessing literary worth? Would approaching a Holocaust journal as a work containing literary aspects undermine the text's plausibility? What role does the author's identity play in relating an authentic depiction of the Holocaust?

It is my intent to examine these questions in relation to Miksa Fenyő's Holocaust journal, Az elsodort ország ['A Country Adrift']. Within Hungary, Miksa Fenyő (1877-1972) is primarily known for his role as editor of Nyugat ['West'], a literary journal that spearheaded modern literary movements in Hungary from 1908 to 1941. Throughout roughly four decades of social upheaval, war, and chaos, Fenyő published countless critiques, reviews, and essays in Nyugat while also acting as executive director of GYOSZ (National Association of Manufactuers), a powerful lobbyist group formed in 1902 with the aim of promoting industry in Hungary. A member of the Hungarian Parliament from 1931 to 1935, Miksa Fenyő's prominent role in Hungary's literary, economic, and political scene came to a halt in 1938, as a result of the AntiJewish Decrees. Forced into hiding during the Holocaust, Fenyö recorded a rare glimpse into the decisions made by Hungary's most influential figures at the time. Following its recent republication in Hungarian, Fenyö's journal has ignited the interest of journalist and historian alike due to its value as a source of information on the Holocaust in Hungary. In spite of Fenyö's strong ties to modern Hungarian literature, his significant critical oeuvre, or the number of literary figures and works mentioned in his journal, Az elsodort ország is categorized as either history or politics in Budapest's main bookstores.

Originally published by Révai Publishers in 1946, the second edition of Fenyő's journal was reprinted by Magvetö Publishers in 1986. While the publisher describes this version as a "corrected edition," within the context of Kadarist Hungary "corrected" actually meant "truncated," or - to put it bluntly_-censored." In spite of the fact that roughly half of the original text was excised, this circumstance is indicated nowhere within the text itself. Unwary readers therefore had no way of knowing what had been removed or altered in the second edition of Miksa Fenyö's journal, the version most accessible to readers. The immense difference between Az elsodort ország's first and second editions emphasizes how vulnerable this type of text is to the whims of those into whose hands they fall. Compared to other prose works, it is far too easy to make a day or two disappear from a personal diary.

Released in 2014 by Park Publishers, the journal's third edition is therefore a highly welcome turn of events in the history of this text. Not only does the new edition reinstate $A z$ elsodort ország's text to its first Révai edition, footnotes also explain the international and local events to which Fenyő refers. Additionally, the journal is followed by a note from the editor

\footnotetext{
${ }^{1}$ http://www.npr.org/sections/thetwo-way/2015/12/31/461606275/mein-kampf-enters-public-domain-arguablyanne-franks-diary-may-too
} 
containing a brief overview of the text's publication history, including the circumstances surrounding its latest inception. An index of names summarizes the multitude of personalities found in Fenyö's narrative, thereby enabling readers to locate and track the presence of various well-known figures in the text itself. Important details pertinent to Fenyö's private life are also provided. Most significantly, the third edition reveals the identities of people Fenyö protected by only using their initials. This highly valuable information would not be available to today's readers without the help of Fenyö's only surviving son, Mario D. Fenyo, who experienced many events described in the journal. The third edition of Az elsodort ország aptly demonstrates how the participation of other family members or confidantes is often needed to render these somewhat encoded works comprehensible to the ordinary reader.

Unlike Anne Frank's journals and notes, the whereabouts of the original manuscript for Az elsodort ország remains unknown; it is therefore impossible to know what form(s) the text may have originally taken. The first Révai edition must be viewed as its most authentic version, as it was published during Fenyő's lifetime. In an exchange witnessed by Mario D. Fenyo, the author informed Révai's editor that he would only allow publication if no changes were made to his journal. In Az elsodort ország's introduction, Miksa Fenyő explains why he did not amend statements proved incorrect after the war: "True, it would not have been right for me to change one letter of these entries, not even for the sake of historical accuracy, because these notes do not belong to me, but to all who were persecuted, all who spent those terrifying ten months pressing their shoulders and their hearts against the thin boards of a door being beaten down with the rifle butts of a murdering horde" [Hát igen, ezeken a följegyzéseken nem volt szabad semmit sem változtatnom, még a történelmi igazság kedvéért sem, mert nem is az enyémek ezek, hanem minden üldözötté, kik abban a rettenetes tíz hónapban vállukat, szívïket nekifeszítették a vékonydongájú ajtónak, melyet a gyilkosok tömege puskatussal döngetett] (Fenyő 2014: 10). ${ }^{2}$ While Fenyő clearly intends his personal account to represent the collective, he ends the introduction with a note reiterating that no further commentary was added to his journal, for his aim was to write his experiences, not history. Miksa Fenyő consciously places his work in an unsettling juxtaposition of personal vs. collective, the writing of history vs. a telling of events. The unique nature of this authorial strategy called my attention to the fact that Az elsodort ország may differ drastically from other Holocaust diaries.

Before Fenyö's journal can be compared to any other first-person account of the Holocaust, the nature of Miksa Fenyő's personal identity deserves further examination. Like many intellectuals of Jewish origin at this time, Fenyő was thoroughly assimilated into Hungarian culture. Born Miksa Fleischmann, he took the Hungarian name of Fenyő as a young man. Although he did not actively participate in any type of organized religion, Fenyő did convert to Catholicism. Fluent in French, German, and Italian, well-versed in Latin as well as ancient Greek, Fenyő wrote exclusively in Hungarian while also using his knowledge of foreign languages to quote from a staggering array of European literature in the original. In spite of the fact that the journal contains vivid portrayals of Fenyö's formative years, no mention is made that any language other than Hungarian was present in his parent's Jewish home. In his later

\footnotetext{
${ }^{2}$ All translations from Hungarian are my own.
} 
memoir, Fenyő offhandedly mentions that he could read Hebrew but did not understand Jewish rituals conducted in this language (Fenyö 1994: 23-41). He also remarks that he had not learned German by the time he began secondary school at the Lutheran Gymnasium in Budapest (Fenyö 1994: 25-26, 34). At the same time, Fenyő never refuted his past and recorded many anecdotes describing his path from being the son of a Jewish tailor to editing Hungary's premier literary journal and participating in the powerful financial organization of GYOSZ. A staunch supporter of his birthplace, Mélykút, located at the tip of Southern Hungary, it is safe to say that Miksa Fenyő remains the only author to immortalize this small village.

Reading Az elsodort ország, it soon becomes clear that Fenyö can decry a world that allows thousands of Jews to be slaughtered, yet still separate himself from possessing a Jewish identity. Most tellingly, atrocities against "the Jews" ['a zsidók'] are quite oddly relayed by means of this definite article. In other words, no collective pronoun - such as "us" "we Jews," or "our fate"- is included in an account that follows everything from his own captivity to the inhuman conditions at the internment camp for Jews in Kistarcsa (Fenyö 2014: 323-324). While referring to "a zsidók" could be interpreted as a commonplace means of expression in Hungarian, as a grammatical tool it still situates Fenyő in a position facing the Jews he is observing, rather than sharing their fate. The following excerpt best exemplifies the paths Fenyö's writing takes when discussing "the Jews" and his own situation:

Not to mention the Jews; I think of their fate with utter pity and horror. If there's anyone whom the word 'heroism' fits, well, this fits them. If it's possible to describe anyone as vivere pericolosamente ['living perilously'], well, this describes them.

And yet how strange - even as a man finds himself overcome with such terror, imagining moment by moment what fate could befall his friends, his children, his own life, the most inconsequential, meaningless thoughts still come to mind. My suspenders aren't any good, must buy new ones. [...] Must write and ask the Manufacturer of Canned Goods, Inc. how their cherry jam can be so excellent when their apricot jam tastes awful and smells like fingernail polish. The only toilet paper to be had is completely unfit for use; newspaper would be far better. Must make sure the grass in my villa's garden is kept trimmed. What a pity there's no candied fruit or bits of chocolate in fruitcake these days; how much worse it is on its own, with just almonds. Having my Jewish nose altered to an Aryan one wouldn't have been a bad idea.

These thoughts and more come to mind; how ashamed I am of myself, as I view myself, a feeling always followed by an attempt at a cliché or two to keep up the cheer: this is the mystery of life, or at least the mystery of its progress. Such is life. C'est la vie. Questa e la vita. So ist das Leben. Just as Alfred Kerr, the critic I revered most as a young man, wrote in one of his reviews. Alfred Kerr-I wonder, can he still be alive? (Fenyö 2014: 89-90). 
Lo Bello, Maya J. "The Holocaust Journal of Miksa Fenyő.” Hungarian Cultural Studies. e-Journal of the American Hungarian Educators Association, Volume 9 (2016): http://ahea.pitt.edu DOI: 10.5195/ahea.2016.230

[A zsidókról már nem is beszélek; mély szánalommal és rémülettel gondolok sorsukra. Ha valakire illik a heroizmus szó, hát rájuk; ha valakiröl elmondhatni, hogy vivere pericolosamente, hát róluk.

Milyen különös, hogy mialatt az ember tele van ilyen rémülettel, és minden pillanatban maga elé idézi barátai sorsát, gyermekei sorsát, a maga sorsát, a legsemmibb dolgokra is tud gondolni, a legjelentéktelenebbeket is elintézni. Nem jó a nadrágtartóm, újat kellene venni...Írni kellene a Konzervipar Rt.-nek, hogy ha ilyen kitünö meggydzsemet tud csinálni, miért olyan pocsék, körömlakkszagú a barackdzsemje. A vécépapíros, amit mostanában kapni, használhatatlan; akár újságpapírt is lehetne helyette használni. Gondoskodni kellene arról, hogy a villa kertjében kaszálják a füvet. Kár, hogy a püspökkenyérben most már nincsenek csodoládédarabok és cukrozott gyümölcs; így egyedül mandulával, kevésbé jó. Zsidós orromat nem ártott volna árjává operáltatni.

Ezek és az ilyenek jutnak eszembe; elrestellem magam elött magam, azután azzal a frázissal próbálom megnyugtatni magam: ez az élet titka, vagy legalábbis a fejlödésé. Ilyen az élet. C'est la vie. Questa e la vita. So ist das Leben. Ahogy Alfred Kerr, ifjúkorom kedves és megbecsült kritikusa irta egy bírálatában. Alfred Kerr, vajon él-e még?]

This excerpt not only exemplifies the fluid, literary style, tight composition and ironic, conversational tone found throughout Fenyö's journal, it also displays how Fenyő differentiates between his own fate and that of "the Jews," "they," or "them." To be fair, Fenyö adapts a similar distance when examining his own, inner world, as signaled by his customary switching to the third-person singular of "a man" or "a person," rather than using the first-person. When judging himself, this distance works to draw the intimate details of his personal thoughts even closer: he is dissecting pieces in order to gain a better understanding of the whole. Throughout this process, his highly ironic reference to his Jewish nose is the closest he comes to equating himself with "the Jews," a weighted comment he tacks on when least expected, following a list of inconsequential items. As black as Fenyö's "punchline" is, his nose is the only physical feature mentioned in an entire range of worldly trappings and inner processes (apparel, digestion, defecation, his former villa) that are seemingly given a more prominent position in the passage. The lack of importance Fenyő places on a feature that has little to do with his inner worldindeed, it only appears in connection with the possibility of being altered - demonstrates what consequence something so very mundane can possess. It does not, however, bring Fenyő any closer to identifying himself with "the Jews" he sincerely pities in the first sentence.

Analyzed within the context of Fenyö's literary past, Alfred Kerr's name circles back to the beginning of Miksa Fenyő's critical career, when Fenyö was dubbed "the Hungarian Kerr" (Kosztolánczy 2009:147) for his devotion to this German theatre critic's work. In some ways the melancholy question, "can he still be alive?" refers not only to Alfred Kerr, but also hints of doubting whether Fenyö-as-critic has still survived. Indeed, the entire journal could be interpreted as a dogged attempt to maintain "the right to criticism," ['a kritika joga'] (Fenyö 2014: 69) as he calls it, the critical stance Fenyő clings to as the most essential aspect of his identity. With its style and composition, Az elsodort ország attests to the fact that Miksa Fenyö remained the highly gifted, articulate critic he was, even while living under constant threat. 
Lo Bello, Maya J. “The Holocaust Journal of Miksa Fenyő.” Hungarian Cultural Studies. e-Journal of the American Hungarian Educators Association, Volume 9 (2016): http://ahea.pitt.edu DOI: 10.5195/ahea.2016.230

Thanks to Fenyö's extensive social network, he was able spend the final year of the war hiding in the homes of friends. Fenyö's connections even made it (at least theoretically) possible for him to leave Hungary. In fact, Fenyő returns to the question of emigration various times in this narrative; each time he reiterates that he could not leave. Doing so would deny him his only remaining role, the kind of active observation he contrasts to the "passive on-looking" (Fenyo" 2014:150) he would be forced to do if he left Hungary. On November 2, 1944, Fenyő feels he should still make use of his connections and apply for Swedish passports, a decision that unleashes an onslaught of guilt and self-castigation (Fenyö 2014: 380) over showing disloyalty to a country that had admittedly stripped him of every aspect of his citizenship. When the passports cannot be attained, Fenyő merely comments, "This was news I was glad to hear, it lifted a heavy weight off my soul. (As to the reason for this heaviness of soul, no rational explanation can be offered.)" [Örültem a hírnek, lelki nyomás alól szabadított fel. (Mely lelki nyomásnak nem is tudnám józan okát adni] (Fenyö 2014: 386). More than any other incident relayed in Az elsodort ország, Fenyő's inability to accept escape under a Swedish passport illustrates how deeply he identified himself as Hungarian.

In spite of the distance Miksa Fenyő places between himself and Jewish Holocaust victims, he reacts to his ordeal the way many Jews did: by maintaining a record of events. Must an author have retained his or her Jewish identity in order to be deemed an authentic source for relaying the Holocaust? While this question cannot be completely answered, it is inadvertently addressed in the next episode: desperate to leave his hiding place for a short walk, Fenyö grows a beard to mask his identity. He ruefully comments: "Ria [his wife, who was not Jewish] brought Mario today. I was very happy to see him. He doesn't approve of the beard I'm growing. Nor does Ria. She says it just emphasizes my already Jewish appearance even more, something she finds quite unnecessary" [Ria ma elhozta Mariót. Igen örülttem neki. Nem helyesli, hogy szakállt növesztek. Ria sem. Azt állítja, hogy ez még csak jobban hangsúlyozza zsidós kinézésemet, ami szerinte felesleges] (Fenyö 2014: 195-196). Just as references to his "Jewish nose" appear throughout the journal, Fenyö's "Assyrian appearance grows and grows" [Szakállam és asszír kinézésem nöttön-nö] (Fenyő 2014: 205) along with his beard. Living as a Holocaust victim, an individual's true identity is no longer relevant: no matter how far he distances himself from being Jewish, Fenyö's reflection in the mirror still shows the same "crooked nose" or bushy beard found in the grotesque, anti-Jewish propaganda of the time. This image is also how Fenyö fears others perceive him when he finally takes a walk down the street: "This afternoon I walked down the street for the first time in two months, to go to the dentist - two houses down. Every person I came face-to-face with asked the same thing: why wasn't the crooked-nosed Jew wearing a yellow star" [Ma délután kimentem az utcára; két hónap óta elöször, a fogorvoshoz, két házzal odébb. Aki szembejött velem, mind azt kérdezte, miért nincs a görbe orrú zsidón sárga csillag] (Fenyő 2014: 82). Fenyö's offhand remarks reveal how dictatorships strip away personal rights and freedoms while simultaneously rendering individuals into caricatures of their previous selves. For me, this reveals the Holocaust's true face in one of its most authentic forms.

At the same time, David Engel's analysis of how threat was perceived in Warsaw ghetto diaries leads to the observation that eyewitness accounts devote remarkably little space to predicting the intentions of Nazi occupiers; diaries therefore do not serve as a predominant basis for determining what ghetto inmates understood about the events unfolding around them (Engels 1999: 81). In this respect, Fenyö's journal is markedly different. An incredible feat in its own right, Miksa Fenyő was already aware of the threat posed by Nazism when he published his 
Lo Bello, Maya J. “The Holocaust Journal of Miksa Fenyő.” Hungarian Cultural Studies. e-Journal of the American Hungarian Educators Association, Volume 9 (2016): http://ahea.pitt.edu DOI: 10.5195/ahea.2016.230

study, Hitler, in 1934. His journal clearly describes the deportations, the robbery of Jews, the attitudes of everyday people willing to turn a blind eye. Fenyo understands all too well what is happening. His comprehension makes it impossible to claim that these events were hidden from view, that nobody in this period had any way of knowing. At one point he records a visit by F. Ödön, a source for information on the events unfolding outside Fenyő's hideaway: "Today I was visited by F. Ödön, someone quite well-informed of what is happening to Jews; he said that according to numbers gathered by the Jewish religious community, roughly six-hundred thousand Jews have been dragged off - yet it's possible they haven't all been killed. He informed me of horror after horror, committed by the Gestapo, all on its own, but assisted quite often by the Hungarian guard and police" [Ma fölkeresett $F$. Ödön, aki a zsidókkal történtekröl meglehetösen jól van informálva; elmondotta, hogy a zsidó hitközség adatai szerint közel hatszázezer zsidót hurcoltak el; lehet, hogy nem mind ölték meg. A borzalmak egész soráról informált, melyeket a Gestapo követett el, önállóan, de igen gyakran a magyar csendörség és a rendörség asszisztenciájával] (Fenyö 2014: 335-336). A few entries later, Fenyö also refers to "ozvicei," (Fenyö 2014: 339) his spelling of the Polish word for Auschwitz, Oświęcim.

In his review of $A z$ elsodort ország's third edition, László Márton expresses his dissatisfaction with Fenyö's interpretation of the times and argues that a man of such education and knowledge should have gone further in rooting out the underlying social and historical causes for the war, rather than merely blaming Hitler for its outbreak (Márton 2014: 21). Márton's calling of Fenyő to account for his lack of deeper insight into the workings of his own time sparked a detailed reply by the historian, Gábor Gyáni. Concerning the issue of accountability in connection to Fenyö's journal, Gyáni states that the historical documents represented by such journals offer a rare glimpse into how people felt, thought, and reacted during a given historical time. As such, Gyáni feels it is mistaken to demand that their authors be aware of factors or events that could only be known by readers living in the present. (Gyáni 2014: 1259). As rational as Gyáni’s advice is, Márton’s opinion shows how Holocaust diaries are not only vulnerable to censorship, but also to an impossibly high level of moral and ethical accountability.

Given his status as a respected novelist, I find it surprising that Márton's review only hints at a few of Az elsodort ország's literary aspects, instead glossing over many of this work's key literary characteristics in favor of its political/historical content. While Gyáni’s interpretation marks the first recent attempt to analyze Fenyö's journal from the point of view of a historian, no effort has been made to dig deeper into Az elsodort ország's possible value as a work of literature. To begin my own examination of Fenyö's journal as a literary text, I turn to David Roskies's reading of Yiddish diaries from the Warsaw ghetto and his description of how these texts demand readers learn how to tell "Holocaust time." According to Roskies, "Holocaust time" entails a sense of duration that becomes an entirely unique, highly individual interpretation (Roskies 1999: 17) of time as bifurcated time, "time cut in half, time-before and time-after; the basic demarcation of time in the literature of the Holocaust" (Roskies 1999: 19). Furthermore, Roskies emphasizes that the greatness of the Oyneg Shabes Archive- a courageous project led by the historian, Emanuel Ringelblum, in an attempt to document events in the Warsaw Ghettolies not only in its rigorous dedication to documenting daily life in the Warsaw ghetto, but also in the fact that "...in the aftermath of the Great Deportation, each surviving chronicler was forced to become threnodist, an interpreter, a theologian, a poet - a new synthesis had to be found." As Roskies asks, "Where, then, does one seek the truth about the destruction of the European Jewry? 
Lo Bello, Maya J. “The Holocaust Journal of Miksa Fenyő.” Hungarian Cultural Studies. e-Journal of the American Hungarian Educators Association, Volume 9 (2016): http://ahea.pitt.edu DOI: 10.5195/ahea.2016.230

Does one find it in the documentary truth of eyewitness accounts or in the subjective truth of the witness-as-threnodist" (Roskies 1999: 27)? As relevant as his question is, Roskies's interpretation does not address the fact that creating an individualized sense of time while simultaneously melding reality into a form of lamentation are issues pertinent to the realm of literature.

In the case of Miksa Fenyő's journal, David Roskies's description of "Holocaust time" is particularly apt. During his captivity, Fenyő understandably counts the days till the war is over, when he and his family can be free again. Each month spent in captivity is marked, predictions are made concerning the war's end, personal anniversaries serve to mark the duration of this individualized time referred to by Roskies. This, however, is just one role time plays in $A z$ elsodort ország. In fact, strange as it may seem, the process of living in "Holocaust time" provided Fenyő with a wealth of opportunities in crafting his work. It is the reader's task to trace the many things time represents in this personal account.

As László Márton also observes, Fenyő deliberately employs time as a dramatic device driving his narrative (Márton 2014: 21). Each time Budapest is bombed, Fenyő regularly intersperses his entries with the time of each explosion or air-raid siren, rendering an essay-like composition into a tense depiction of intellectual endeavor in the face of absolute war. For the reader, brief recordings such as "American bombs are falling at this very moment" [e pillanatban sürün hullanak az amerikaiak bombái] (Fenyo 2014: 29), “9:45. Alarm sounds" [9 óra 45. Riasztás] (Fenyő 2014: 223), and “12: 45. Air raid over” [12 óra 45. Légiriadó elmúlt] (Fenyő 2014: 225), punctuate Fenyő's musings in a way that not only brings the war closer, but symbolically recreates the feeling of the banging rifle butts featured as a metaphor in Fenyö's introduction. As readers living in the present, we already know the end: when Fenyő wonders what has happened to his missing friend, Endre Bajcsy-Zsilinszky, or as the siege of Budapest approaches, each day becomes a page we turn with a kind of greedy dread, unwilling to face the increase of Fenyö's personal pain, yet still eager to discover when he will know what we already do. This text reverberates with the question of "when," rather like waves of sound pulsing from a bell rung in alarm.

Fenyő's careful construction - many entries could stand as separate articles — and usage of air-raids as narratological devices are two of many clues indicating that this is no ordinary jotting down of daily events. The presence of flashbacks describing past episodes in Fenyö's life add drama while also filling the reader in on important background information. The most significant flashback comes near the beginning, when Fenyö returns to the days before he started writing the journal to describe how he learned he was sought by the Gestapo and escaped just in time (Fenyő 2014: 44-45). His other flashbacks - in which he returns to his childhood in Mélykút, (Fenyő 2014: 188-194) or trips taken to Italy (Fenyö 2014: 127-130)_provide an opportunity for Fenyő to escape his surroundings while also adding a great deal of color and lyricism to a frequently depressing narrative. Each flashback returns to the journal's main topic in a perfect dovetail that proves Fenyö's attention to narrative composition.

Just as very few people would continue writing a detailed, well-written essay while bombs fall all around them, it seems possible that few diarists record their internal debate over what title would be best for their "journal." Indeed, Fenyö devotes most of his introduction to the question of why he finally chose the title, Az elsodort ország (Fenyő 2014: 7-9). At the journal's end, after relaying an incredibly well-written, highly dramatized description of the siege of Budapest, Fenyő emerges from the rubble of the war only to announce the journal's title, what he 
feels can only be A legyilkolt ország ['A Country Murdered'] (Fenyö 2014: 532) The question of the journal's title thereby answers the main question of what fate awaits Hungary. Additionally, it loops back to the work's beginning in a circular composition negating any relationship with the fragmentary nature of most journal entries.

Unlike most diarists, Fenyő writes with an obvious audience in mind, mainly his son Mario. Moved from hiding-place to hiding-place and exposed to what was happening in Hungary throughout 1944-1945, Mario was presumably aware of the daily challenges the war entailed. Still uncertain of his family's survival, Fenyö could not have been collecting proof of atrocities for the Mario of the journal; instead, he addresses his efforts to the future symbolized by Mario, the next generation Fenyő hopes will use his entries to bring justice to the persecuted. Fenyő's personal handling of time therefore leads to a dual layering of the past, present and future. On an abstract level, Fenyő analyzes Hungary's past, present, and future in order to answer the questions he poses: how did it come to this? What is happening now? What will the future bring to Hungary? At the same time, Fenyö repeats this structure on a far more personal level. The present is represented by Fenyö's fate, clearly linked to the war's progress in the following comment: "Cherbourg — about to fall. Ancona - about to fall. And so I feel—am I" [Cherbourg esedékes. Ancona esedékes. Azt hiszem, én is] (Fenyő 2014: 15). As previously mentioned, the flashbacks recreate important episodes from Fenyö's past. Finally, addressing his narrative to his nine-year-old son (Fenyő had three sons and one daughter and the children from his first marriage-György, Iván and Anna Fenyő - were adults at the time of the war) turns the future from an abstract concept into a concrete individual. Always distant, always longed for, always in danger of being snuffed out: this is the future in its most infinitely precious form. As a reader, I must confess that following Fenyö's recording of the war's progression would be far less interesting if it were not for this consciously individualized depiction of time.

In possession of a firm beginning and end, a well-developed cast of characters, a concrete audience, a title and clearly traceable timeline, Az elsodort ország becomes a narrative so cunningly constructed that it appears to be a journal while actually bearing many characteristics of a novel. Fenyő summarizes the numerous paradoxes surrounding the nature of his writing in the following quotation:

The moment pen is taken into hand, a certain pose has already been taken. A person is already sifting, discarding one thought in favor of the other, weighing what effect his words may have: writing is a matter of telling lies. We are only sincere as long as we remain unaccountable; he who writes immediately becomes accountable, and can no longer remain sincere (Fenyő 2014: 55).

[Mihelyt az ember tollat vesz a kezébe, már egy bizonyos pózba helyezkedik. Már szelektálnia kell, az egyik gondolatot elvetnie, mondanivalójának hatásfokát mérlegelnie: az irás hazug dolog. Csak addig vagyunk öszinték, mig ellenörizhetetlennek tartjuk magunkat; aki ir, az módot ad az ellenörzésre, az már nem tud öszinte lenni.] 
Lo Bello, Maya J. “The Holocaust Journal of Miksa Fenyő.” Hungarian Cultural Studies. e-Journal of the American Hungarian Educators Association, Volume 9 (2016): http://ahea.pitt.edu DOI: 10.5195/ahea.2016.230

In the field of literary theory, it is virtually impossible to discuss the nature of personal literature without referring to Philippe Lejeune's work, On Autobiography. In Lejeune's definition, diaries are not retrospective; a curious conundrum given Fenyő's frequent usage of flashbacks. In addition, author, narrator, and protagonist must be identical (Lejeune1989: 4). According to Lejeune, the author-narrator connection is made through usage of a title (such as My Life, The Story of My Life) or in the initial section of the text, where the narrator clearly acts like the author of this text, thereby leaving the reader in no doubt as to whom "I" refers to, even if this "I" is not named in the text itself (Lejeune 1989: 14). The directives and explanations contained in Fenyő's introduction to Az elsodort ország are examples of this implicit connection between author and narrator. At the same time, Fenyö's decision to use a title that alludes to a well-known work—Dezső Szabó's 1919 novel, Az elsodort falu ['A Village Adrift']—discards an opportunity to strengthen the author-narrator link in favor of placing his journal in a literary context.

True, Fenyő's identity as author cannot be denied. As mentioned previously, his determined portrayal of himself as an intellectual, critic, and author is perhaps the only stable factor present throughout the many questions surrounding his identity. The limits surrounding Lejeune's theories on author-narrator identity must be acknowledged in the case of Holocaust diaries, works of life-writing that record identity's disintegration. Furthermore, as the Holocaust author records events, the narrator's loss of identity forges the link between narrator and protagonist. In the case of Fenyö's journal, I argue that it is precisely this aspect that forms a basis for how authentic his record is perceived to be. While Lejeune refers to autobiography in his definition of the referential pact - the implicit contract between reader and author in which the author promises to tell the whole truth (Lejeune 1989: 22)—Fenyö's insistence that any kind of writing is always the telling of lies refutes Lejeune's theory while also undermining his own authorial status as a recorder of the truth. What could be the purpose of making such a move?

Citing Gide and Mauriac as examples, Lejeune argues that some authors credit their literary works as containing more truth than their autobiographies in order to turn the question of truth on its head (Lejeune 1989: 27). While it can be argued that autobiography is a separate genre from diary, it is my contention that the risks Miksa Fenyő takes as he skates along the edge of documentary and literature, truth and lies, performs a similar task in his journal. Just as Fenyő preserves his journal as his only space for free expression, he also creates a space for the reader to practice his or her own "right to criticism," even in the face of a text that bears witness and accepts memory's primal role.

To return to David Roskies's question of which is truer, the documentary truth of an eyewitness account or the subjective truth of witness-as-threnodist, I can only answer that I do not know. Fenyö's handling of this dilemma indicates that much work remains in the analysis of Holocaust diaries. It is my suggestion that the inherent vulnerability of Holocaust diaries - open to censorship, subjected to moral and ethical judgments, used for their value as historical documentation - as well as the strategies authors use to preserve a disintegrating identity provide two possible approaches in understanding such special texts.

The example of Miksa Fenyő's journal indicates that Holocaust time has other, more long-term effects. Writing a personal account of the Holocaust bifurcates the author as well, turning him into someone whose identity is only that measured and contained by the Holocaust itself. In the case of the Warsaw ghetto diaries, these entries are often the only traces left behind of an individual struggling to survive as the clock ticks to the railway schedule of Holocaust 
Lo Bello, Maya J. “The Holocaust Journal of Miksa Fenyő.” Hungarian Cultural Studies. e-Journal of the American Hungarian Educators Association, Volume 9 (2016): http://ahea.pitt.edu DOI: 10.5195/ahea.2016.230

time. In spite of their frequent status as fragments, Holocaust diaries become the work for which the author is known, a curious state given the fact that personal accounts are generally supplementary in nature. While diaries individualize the Holocaust, reading these individuals solely as witnesses strips them of their previous identities while also restricting the text to one purpose, one interpretation. The complex nature of Az elsodort ország underscores a need to examine these texts on several levels and - if possible - within the context of the author's entire oeuvre.

Fenyő's usage of literary techniques is clearly a legacy of his career as a Nyugat editor, critic, and essayist, a fact that cannot be emphasized enough since it defines his treatment of the Holocaust. Not only a carefully constructed narration, Fenyő's journal provides many sources of documentary evidence as well. In addition to a wide assortment of essays, reviews, letters to political leaders and critiques, Fenyö's journal contains a wealth of newspaper articles, comments, conversations, handbills, and radio reports all painstakingly copied into the journal as a means of recording a world he could not participate in. Fenyö thereby broadens the scope of his entries in order to bear witness to events he does not in fact see, but rather gleans from other sources

As obvious as it is that Fenyő spent the war in hiding, the amazing activity present in this text—visitors, radio reports, access to local and foreign newspapers, more visitors, phone calls, more radio reports - makes it seem like Fenyő is at the hub of a bustling, Holocaust control center rather than spending months in the equivalent of a closet. Whether this is a true portrayal or not really does not matter: this is Fenyö's recreation of "active observation," his reason for staying in Hungary rather than fleeing when he has the opportunity. Somewhat like Emanuel Ringelblum, Miksa Fenyö single-handedly establishes his own historical archive that is not secreted in milk cans under ghetto floorboards, but gathered into one work. In literature, the best way to compile such varied material into one narrative is to employ the very eclectic genre of diary, a text whose only formal requirement is placing a date at the beginning of each entry. This perhaps explains why Fenyö did not choose autobiography or memoir to transpose his wartime experiences into his attempt at the most authentic depiction of what it was like to live during the Holocaust in Budapest, Hungary.

In the course of the Second World War, Miksa Fenyő lost virtually everything that represented his life's work. After decades of success, Nyugat, the journal he lovingly nurtured, like he did the roses in his garden, could no longer be published. The anti-Jewish decrees forced him to give up his career at GYOSZ, his position as a member of Parliament, and his work as a critic. In order to remain out of the Gestapo's hands, his second wife and youngest child had to change their last names. His older children worked in labor camps and barely managed to escape the ghetto. His home and possessions were either destroyed or stolen, his friends either killed, sent to labor camps, or forced to flee. After the war, Fenyő was forced by the Rákosi regime to leave Hungary, the country whose fate formed the center of his work, Az elsodort ország. This, too, is a part of his narrative. Yet this story could not have been told without the tools and knowledge he gained in all of his capacities as critic, editor, essayist, GYOSZ director, and politician. His journal is a true reflection of the richness of Fenyö's entire oeuvre. Its acceptance of an uncomfortable position someplace between personal and collective, Jewish and Hungarian, history and experience, novel and journal is the work of someone who embraced the consequences of being neither/nor. While I find Az elsodort ország to be one of Fenyö's best works, I see its main strength not merely in the fact that it provides an eyewitness account of the 
Lo Bello, Maya J. "The Holocaust Journal of Miksa Fenyő.” Hungarian Cultural Studies. e-Journal of the American Hungarian Educators Association, Volume 9 (2016): http://ahea.pitt.edu DOI: 10.5195/ahea.2016.230

Holocaust and the Second World War in Hungary, but in its ability to synthesize a narration that confounds the four walls dictated by Holocaust time - in both 1944 and today.

\section{Works Cited}

Dwyer, Colin. 2015. "Mein Kampf Enters Public Domain; Arguably Anne Frank’s Diary May, Too." NPR.org. December 31. http://www.npr.org/sections/thetwoway/2015/12/31/461606275/mein-kampf-enters-public-domain-arguably-anne-franksdiary-may-too

Engel, David. 1999. “'Will They Dare?': Perceptions of Threat in Diaries from the Warsaw Ghetto." In Holocaust Chronicles: Individualizing the Holocaust through Diaries and Other Contemporaneous Personal Accounts. Ed. Robert Moses Shapiro. Jersey City: KTAV Publishing House.

Fenyő, Miksa. 1994. Önéletrajzom ['My Autobiography']. Budapest: Argumentum. — 2014. Az elsodort ország ['A Country Adrift'], 3rd ed. Budapest: Park Könyvkiadó. Gyáni, Gábor. 2014. "A napló mint kordokumentum" ['The Diary as Historical Document']. Holmi, 10: 1258-1263.

Kosztolánczy, Tibor. 2009. A fiatal Osvát Ernö ['The Young Ernő Osvát']. Budapest: Universitas.

Lejeune, Philippe. 1989. On Autobiography. Minneapolis: University of Minnesota Press.

Márton, László. 2014. "Bújt az üldözött" ['The Quarry in Hiding']. Élet és irodalom, August 14: 21.

Roskies, David G. 1999. "Landkentenish: Yiddish Belles Lettres in the Warsaw Ghetto." In Holocaust Chronicles: Individualizing the Holocaust through Diaries and Other Contemporaneous Personal Accounts. Ed. Robert Moses Shapiro. Jersey City: KTAV Publishing House. 